\title{
Perpetuation of Rice Sheath Blight Pathogen (Thanatephorus cucumeris) Under Temperate Conditions of Kashmir, India
}

\author{
Mohammad Najeeb Mughal $^{1 *}$, Mushtaq Ahmed ${ }^{1}$, Sabiya Bashir ${ }^{2}$, Ali Anwar ${ }^{3}$, \\ K.A. Bhat ${ }^{1}$, Z.A. Lone ${ }^{1}$, Imran Bashir ${ }^{1}$, N.A. Bhat ${ }^{1}$, Zahoor Ahmed Dar ${ }^{1}$, Mudasri Ahmed \\ Bhat, Seerat un Nissa ${ }^{2}$, R.A. Wani ${ }^{2}$ and S.A. Hakeem ${ }^{1}$ \\ ${ }^{1}$ Division of Plant Pathology, Faculty of Agriculture Sher-e- Kashmir University of \\ Agricultural Sciences and Technology of Kashmir, Wadura-193201, Maharashtra, India \\ ${ }^{2}$ DARS, SKUAST-K, Rangrath-190001, India \\ Division of Plant Pathology, Shalimer, India \\ *Corresponding author
}

A B S T R A C T

\section{Keywords}

Perpetuation, Rice, Seed, Sheath blight, Straw, Thanatephorus cucumeris.

\section{Article Info}

Accepted:

26 September 2017

Available Online:

10 November 2017
The studies conducted on mode of perpetuation of sheath blight pathogen (Thanatephorus cucumeris) of rice (Oryza sativa L.) in/on rice seeds, plant debris and through sclerotia was studied at different placement conditions viz., on soil surface, at $5 \mathrm{~cm}$ soil depth and in-door under roof cover after crop harvest. The rice seeds were found to harbour externally viable pathogen up to five months from the harvest. The pathogen survived the crop less off-season as mycelium in infected straw and as sclerotia when placed either on soil surface, or $5 \mathrm{~cm}$ deep in soil or in-doors under roof cover. However, the viability decreased at all the placements with increase in storage period. After seven months, the maximum straw bits $(68.66 \%)$ harboured viable $T$. cucumeris when placed in-doors under roof cover followed by placement at $5 \mathrm{~cm}$ soil depth $(45.50 \%)$ and on soil surface $(34.33 \%)$. In case of sclerotia, maximum viable scterotia $(91.04 \%)$ were found andoors under roof cover, followed by placement at $5 \mathrm{~cm}$ soil depth $(74.71 \%)$ and on soil surface $(64.66 \%)$.

\section{Introduction}

Rice (Oryza sativa L.) is the most important cereal crop of India. It is staple food crop of Jammu and Kashmir where it occupies 261.35 thousand hectare area with an annual production of 5001 thousand tones (Kaloo et al., 2014). The crop is attacked by a number of fungal, bacterial and viral diseases, which inflict heavy yield losses every year. Sheath blight of rice has attained the status of a major disease in the recent past from what was described as a minor disease by Ramakrishna distribution and now occurs throughout the temperate and tropical rice production areas, being most prominent where rice is grown under intense, high fertility production system (Eizenga et al., 2002). Sheath blight of rice was first reported in India by Paracer and Chahal (1963), while Mir (1986) reported it from Kashmir. The sheath blight of rice caused by Thanatephorus cucumeris [Anamorph: Rhizoctonia solani Kuhn] is one 
of the important biological constraints in achieving the stable rice production. The disease can result in yield losses ranging from 20 to 50 per cent (Rajan, 1987). However, under conditions of heavy severity, yield loss of more than 70 per cent has been reported from Chennai, India (Baby, 1992), and even complete crop failure has also been reported in Vietnam (Ou, 1992).

The perpetuation of the pathogen in any crop eco-system forms an important component of recurrence of any endemic or epidemic disease. T. cucumeris is known to survive between seasons as dormant mycelium in infected rice straw, in/on rice seeds and sclerotia (Singh, 1998; Acharya et al., 2004) and weeds/crops plants (Acharya and SenGupta, 1998). Survival of the pathogen during the off season may provide potential source of primary inoculum of $T$. cucumeris in ensuing cropping season. It is considered essential for adopting judicious control measures as the disease is prevalent in entire rice growing areas of Kashmir valley and therefore, studies on this aspect were conducted.

\section{Materials and Methods}

The perpetuation of pathogen was studied through seeds, infected straw and sclerotia.

\section{Perpetuation in/on seeds}

The seeds collected at harvest from severely infected rice plants (cv. Jhelum) were stored in cotton cloth bags in laboratory and assessed for presence of the pathogen at monthly intervals. The study was conducted using two separate methods viz., agar plate and paper towel method.

\section{Agar plate method}

Three hundred seeds were taken at monthly intervals from the diseased seed samples to study external and/or internal nature of perpetuation of the pathogen. Half of the seeds were surface sterilized with 0.1 per cent mercuric chloride for 30 seconds followed by three subsequent rinses in sterilized distilled water and placed on 2 per cent water agar medium in sterilized Petri plates $(90 \mathrm{~mm}$ ) under aseptic conditions of laminar air flow. Ten seeds were placed aseptically in each Petri dish and incubated at $28 \pm 2^{\circ} \mathrm{C}$ for 48 hours. Five such Petri dishes were maintained and observed for viability of pathogen every month. Rest half of seeds were inoculated on 2 per cent sterilized water agar medium and incubated without surface sterilization to study the possibility of external seed borne nature of the pathogen. The per cent seeds exhibiting $T$. cucumeris growth was recorded as an index of pathogen perpetuation through seeds.

\section{Paper towel method}

Fifty surface sterilized and unsterilized seeds were separately placed in the grooves of sterilized seed germination papers rolled after sprinkling distilled water and incubated at $28 \pm 2^{0} \mathrm{C}$. In all, 150 seeds of each category were assessed for $T$. cucumeris growth and per cent seeds harbouring T. cucumeris was calculated.

\section{Perpetuation through plant debris (diseased stem) and sclerotia}

The paddy straw infected with $T$. cucumeris was cut into $3-5 \mathrm{~cm}$ long pieces, put in nylon mesh bags and placed separately under different placement conditions viz., indoors/under-roof conditions, on soil surface and buried $5 \mathrm{~cm}$ deep in soil. The samples from the bags containing infected straw bits were randomly drawn from all the placement conditions separately at monthly intervals. The infected straw bits were thoroughly 
washed with tap water, surface sterilized with sodium hypochloride (1\%) for 30 seconds, and rinsed thrice with distilled sterilized water to remove the traces of sodium hypochloride. These bits were then dried on sterilized blotter paper to remove the excess of water, aseptically placed on Petri plates containing sterilizes PDA amended with streptomycin sulphate $\left(200 \mu \mathrm{g} \mathrm{ml}{ }^{-1}\right)$ and incubated at $28 \pm 2{ }^{\circ} \mathrm{C}$. Observations on number of straw bits exhibiting $T$. cucumeris growth were recorded after two days of incubation and expressed as per cent infected straw bits exhibiting mycelial growth of $T$. cucumeris by using the following formula:

Per cent infected straw bits exhibiting T.cucumeris growth $=$ (Total no. of infected straw bits exhibiting T. cucumeris growth / Total no. infected straw bits examined) $\times 100$

\section{Perpetuation through sclerotia}

Sclerotia harvested from 20 days old culture of $T$. cucumeris were put in double layer of $1.7 \mathrm{~mm}$ diameter nylon mesh bags at the rate of 150 sclerotia per bag. These bags were placed on soil surface and buried $5 \mathrm{~cm}$ deep in soil on well-marked areas. Besides, sclerotia were also placed in Khadi bags in laboratory at room temperatures and assessed for their viability at monthly intervals. The sclerotial samples placed at soil surface and $5 \mathrm{~cm}$ soil depth were randomly drawn at monthly interval and collected in $250 \mathrm{ml}$ flask containing $150 \mathrm{ml}$ water and placed on a wrist-action shaker to remove the adhering soil particles (Roy, 1986).

The sclerotia placed at indoor under laboratory conditions in Khadi bags were only thoroughly washed with sterilized distilled water. The sclerotia were then surface sterilized with sodium hypochloride (1\%) for $1.5 \mathrm{~min}$ and placed in Petri plates containing sterilized PDA amended with $200 \mu \mathrm{g} \mathrm{ml}$ streptomycin sulphate and incubated at $28 \pm 2{ }^{\circ} \mathrm{C}$. The sclerotial viability was recorded as the per cent sclerotia germinated using following formula:

No. of sclerotia germinated Per cent sclerotial viability = ------------ x 100 Total No. of sclerotia examinated

\section{Results and Discussion}

\section{Perpetuation through seeds}

Random seed samples collected from diseased rice plants after harvest, were examined for the presence of $T$. cucumeris growth using standard agar plate and paper towel methods, separately for surface sterilized and unsterilised seeds.

\section{Using surface sterilized seeds}

The results (Table 1) obtained, indicated that none of the surface sterilized seeds exhibited growth of the $T$. cucumeris either on agar plate or on germination paper, indicating that the pathogen was not internally seed borne.

\section{Using unsterilized seeds}

Persual of the data (Table 1) revealed that highest percentage of seeds (6.17\%) harbouring viable T. cucumeris was recorded immediately after crop harvest (November), followed by that in December (4.00). A decrease in per cent seeds possessing viable T. cucumeris was observed as the storage period advanced such that no seed was found to harbour viable $T$. cucumeris after five months.

The agar plate and paper towel methods differed significantly in assessing the viable T. cucumeris from seed samples. On an average, agar plate method resulted in determining the higher percentage $(2.46 \%)$ of 
seeds harbouring viable $T$. cucumeris than paper towel method (1.67). Using agar plate method, the highest percentage $(7.67 \%)$ of seeds were found to harbor the viable $T$. cucumeris immediately after harvest (November) which decreased gradually as storage period advanced such that only 0.67 per cent seeds exhibited viable $T$. cucumeris four months after harvest (March), while no seed exhibited $T$. cucumeris growth five months after harvest (April) and onwards.

Using Paper towel method, the maximum number of the seeds exhibiting T. cucumeris growth were only 4.67 per cent immediately after harvest (November). The number of infected seeds showed a gradual decrease to 1.33 two months (January) after the harvest and 0.00 per cent four months (March) after the harvest.

\section{Perpetuation in/on soil}

The possibility of perpetuation of pathogen in/on soil through diseased straw (plant debris) and sclerotia were investigated

Table.1 Viability of Thanatephorus cucumeris in infected rice straw kept under different conditions after crop harvest

\begin{tabular}{|c|c|c|c|c|}
\hline \multirow[t]{2}{*}{ Year/Month } & \multicolumn{4}{|c|}{ Mycelial viability (\%) in infected rice straw } \\
\hline & On soil & $\begin{array}{c}\text { At } 5 \text { cm soil } \\
\text { depth }\end{array}$ & $\begin{array}{c}\text { In-doors under } \\
\text { roof cover } \\
\end{array}$ & Mean \\
\hline \multicolumn{5}{|l|}{ Ist Year } \\
\hline November & $74.67(59.55)$ & $83.33(65.90)$ & $100.00(90.00)$ & $\begin{array}{c}\text { 86.00 } \\
(\mathbf{7 1 . 8 9})\end{array}$ \\
\hline December & $69.33(56.37)$ & $72.00(58.05)$ & $95.33(77.51)$ & $\begin{array}{r}78.88 \\
(63.97)\end{array}$ \\
\hline \multicolumn{5}{|l|}{$2^{\text {nd }}$ Year } \\
\hline January & $53.33(46.90)$ & $\begin{array}{c}68.67 \\
(55.96)\end{array}$ & $87.33(69.14)$ & $\begin{array}{c}69.77 \\
(\mathbf{5 7 . 3 3})\end{array}$ \\
\hline February & $36.00(36.86)$ & $\begin{array}{c}60.67 \\
(51.16)\end{array}$ & $77.33(61.56)$ & $\begin{array}{c}58.00 \\
(49.86)\end{array}$ \\
\hline March & $22.67(28.43)$ & $41.33(40.00)$ & $66.67(54.73)$ & $\begin{array}{c}43.55 \\
(41.05)\end{array}$ \\
\hline April & $13.33(21.41)$ & $\begin{array}{c}23.33 \\
(28.88)\end{array}$ & $53.33(46.90)$ & $\begin{array}{c}29.99 \\
(32.39)\end{array}$ \\
\hline May & $\begin{array}{c}5.33 \\
(13.34)\end{array}$ & $12.67(20.85)$ & $40.00(39.23)$ & $\begin{array}{c}19.33 \\
(24.47)\end{array}$ \\
\hline June & $0.00(0.33)$ & $2.00(8.13)$ & $29.33(32.79)$ & $\begin{array}{c}10.44 \\
(18.85)\end{array}$ \\
\hline Mean & $\begin{array}{c}34.33 \\
(32.92)\end{array}$ & $\begin{array}{c}45.50 \\
(41.11)\end{array}$ & $\begin{array}{c}68.66 \\
(58.98)\end{array}$ & \\
\hline \multicolumn{5}{|l|}{$\mathrm{CD}(\mathrm{P}=\mathbf{0 . 0 5})$} \\
\hline Months & 1.62 & & & \\
\hline Placement & 0.71 & & & \\
\hline Months x placement $=$ & 2.20 & & & \\
\hline
\end{tabular}


Table.2 Perpetuation of Thanatephorus cucumeris in/on rice seeds collected from infected tillers in autumn and assessed at monthly intervals during storage

\begin{tabular}{|c|c|c|c|c|c|c|c|}
\hline \multirow[t]{3}{*}{ Month } & & \multicolumn{6}{|c|}{ Per cent seeds exhibiting $R$. solani growth } \\
\hline & & \multicolumn{3}{|c|}{ Surface sterilized seed } & \multicolumn{3}{|c|}{ Unsterilized seeds } \\
\hline & & $\begin{array}{c}\text { Paper towel } \\
\text { method }\end{array}$ & $\begin{array}{l}\text { Agar plate } \\
\text { method }\end{array}$ & Mean & $\begin{array}{c}\text { Agar } \\
\text { plate method }\end{array}$ & $\begin{array}{c}\text { Paper } \\
\text { towel method }\end{array}$ & Mean \\
\hline \multicolumn{8}{|l|}{ Ist Year } \\
\hline \multicolumn{8}{|l|}{$2^{n d} Y e a r$} \\
\hline January & & $0.00(0.70)$ & $0.00(0.70)$ & $0.00(0.70)$ & $4.67(2.27)$ & $1.33(1.35)$ & $3.00(1.81)$ \\
\hline February & & $0.00(0.70)$ & $0.00(0.70)$ & $0.00(0.70)$ & $1.33(1.35)$ & $0.67(1.08)$ & $1.00(1.21)$ \\
\hline June & & $0.00(0.70)$ & $0.00(0.70)$ & $0.00(0.70)$ & $0.00(0.70)$ & $0.00(0.70)$ & $0.00(0.70)$ \\
\hline Mean & & $0.00(0.70)$ & $0.00(0.70)$ & $0.00(0.70)$ & $2.46(1.50)$ & $1.67(1.16)$ & \\
\hline \multicolumn{8}{|l|}{$\mathrm{CD}(\mathrm{P}=\mathbf{0 . 0 5})$} \\
\hline Month & & - & & & & & \\
\hline Method & : & - & & 0.20 & & & \\
\hline Months x Method & : & - & & 0.58 & & & \\
\hline
\end{tabular}


Int.J.Curr.Microbiol.App.Sci (2017) 6(11): 3706-3713

Table.3 Viability of sclerotia of rice sheath blight pathogen (Thanatephorus cucumeris) under different conditions after crop harvest

\begin{tabular}{|c|c|c|c|c|c|}
\hline \multirow{2}{*}{\multicolumn{2}{|c|}{ Year/Month }} & \multicolumn{3}{|c|}{ Viable sclerotia $(\%) *$} & \multirow[b]{2}{*}{ Mean } \\
\hline & & On soil & At $5 \mathrm{~cm}$ soil depth & Under roof cover & \\
\hline \multicolumn{6}{|l|}{$I^{\text {st }}$ year } \\
\hline November & & $100.00(90.00)$ & $98.67(83.37)$ & $100.00(90.0)$ & 99.55 (87.79) \\
\hline December & & 98.67 (83.37) & $96.67(79.59)$ & $100.00(90.0)$ & $98.44(84.28)$ \\
\hline \multicolumn{6}{|l|}{$2^{\text {nd }}$ year } \\
\hline January & & $86.67(68.58)$ & $90.00(71.56)$ & $98.67(84.58)$ & $87.88(74.50)$ \\
\hline February & & $72.33(58.28)$ & $87.67(69.44)$ & $96.33(79.59)$ & $85.44(68.88)$ \\
\hline March & & $54.67(47.67)$ & $77.33(61.56)$ & $94.67(76.70)$ & 75.55 (61.96) \\
\hline April & & $44.33(41.74)$ & $61.33(51.55)$ & $89.33(70.95)$ & $64.99(54.73)$ \\
\hline May & & $35.33(36.46)$ & $50.67(45.38)$ & $78.67(62.49)$ & 54.89 (48.11) \\
\hline June & & $25.33(30.21)$ & $35.33(36.46)$ & $70.67(57.21)$ & 44.89 (41.95) \\
\hline Mean & & $64.66(57.03)$ & $74.71(62.35)$ & $91.04(76.19)$ & \\
\hline \multicolumn{6}{|l|}{$\mathrm{CD}(\mathrm{P}=0.05)$} \\
\hline Months & : & .61 & & & \\
\hline Method & : & .93 & & & \\
\hline Months x Method & : & .79 & & & \\
\hline
\end{tabular}




\section{Perpetuation through straw}

The infected rice straw bits kept under different conditions revealed that irrespective of straw placements, highest per cent infected straw bits exhibited T. cucumeris growth $(86.00 \%)$ immediately after crop harvest in November followed by December and January i.e., 77.88 and $69.77 \%$, respectively. There was a gradual decrease in straw bits exhibiting $T$. cucumeris growth as the storage period advanced such that a minimum of 19.33 per cent straw bits exhibited $T$. cucumeris growth six months after harvest (May) followed by 10.44 per cent seven months after the harvest (June). On an average, infected straw bits placed in-door under roof cover harboured the maximum straw bits exhibiting $T$. cucumeris growth (68.66\%) followed by the placement at $5 \mathrm{~cm}$ depth (45.50); placement in soil surface showed the minimum (34.33\%) growth. There existed a significant interaction between the placement condition and the storage period. The straw bits placed on the soil surface exhibited 74.67 and 69.33 per cent $T$. cucumeris viability in November and December, respectively. The viability of the pathogen showed a gradual decline such that only 5.33 per cent straw bits exhibited $T$. cucumeris viability six months after harvest (May), which was completely lost $(0.00 \%)$ seven months (June) after harvest of crop. The straw bits buried $5 \mathrm{~cm}$ depth in soil showed 83.33 and 72.00 per cent growth of the pathogen in November and December, respectively. Again there is gradual decline in pathogen viability that reaches 2.00 per cent seven months after crop harvest (June) (Table 2).

When placed in-doors under roof covers, viability of $T$. cucumeris was recorded 100.00 per cent immediately after harvest in November. However, the viability of the $T$. cucumeris was decreased to 95.33 per cent in
December. A gradual decrease in viability of T. cucumeris with increase in storage period such that only 29.33 per cent straw bits exhibited viability of $T$. cucumeris seven months after the harvest (June).

\section{Perpetuation through sclerotia}

The samples of sclerotia of T. cucumeris kept either in/on soil or in-door under roof cover, were drawn at monthly intervals and assessed for their viability. The data (Table 3 ) revealed that the sclerotia remained viable in considerable proportions from crop harvest till next seed sowing under all the placement conditions studied. On an overall basis, the number of viable sclerotia was maximum (91.04\%) when the sclerotia were placed under roof cover. At $5 \mathrm{~cm}$ soil depth placement, the sclerotial viability was 74.71 per cent whereas on soil surface least $(64.66 \%)$ sclerotia remained viable. Irrespective of the condition of sclerotial placement, the maximum number of sclerotia (99.55\%) was viable immediately after crop harvest in November. The viability gradually decreased as the placement period advanced such that only 64.99 per cent viable sclerotia were observed five months after crop harvest (April) and only 44.89 per cent seven months after crop harvest (June). There existed a significant interaction between the sclerotial placement condition and the storage period. The sclerotia placed on the soil surface exhibited 100.00 per cent viability immediately after crop harvest (November) and 98.67 per cent in December. The viability showed a gradual decline as the storage period advanced reaching a minimum of 25.33 per cent seven months after harvest (June). Similarly, the sclerotia buried in the soil showed 98.67 per cent viability immediately after crop harvest in November and 96.67 per cent in December. In this case also, the viability showed a gradual decline reaching a minimum of 35.33 per cent seven 
months after crop harvest (June). When placed indoors under roof covers, the sclerotia retained full viability $(100.00 \%)$ for the first two months i.e. November and December. In January also a high proportion of 98.67 per cent sclerotia exhibited viability. Thereafter a gradual decrease in sclerotial viability was observed reaching a minimum of 70.67 per cent seven months after harvest (June).

\section{References}

Acharya, S. and SenGupta, P.K. 1998. Collateral hosts of rice sheath blight of fungus Rhizoctonia solani. International Rice Research Newsletter 35: 89-90

Acharya, S., Basu, A., Sarkar, M.K. and Gupta, P.K.S. 2004. Seed borne infection in sheath blight of rice and its effect on seedling health. Indian Phytopathology 57: 82-83.

Baby, U.I. 1992. Studies on the control of rice sheath blight through the integration of fungal antagonists and organic amendments. Tropical Agriculture 70: 240-244.

Eizenga, G.C., Lee, F.N. and Rutger, J.N. 2002. Screening Oryza species plants for rice sheath blight resistance. Plant Disease 66: 808-812.

Kaloo, M J.; Patidar, R and Choure, T., 2014.
Production and Productivity of Rice in Jammu and Kashmir: An Economic Analysis. International Journal of Research 1: 2348-6848

Mir, N.M. 1986. Important Diseases of Rice. Rice Production Training Programme Manual Rice Research Station, SKUAST, Khudwani, Anantnag (J\&K), pp 54-56, June $23^{\text {rd }}-26^{\text {th }}$

Ou, S.H. 1992. Rice Diseases. Commonwealth Mycological Institute, Kew, England, p. 368.

Paracer, C.S. and Chahal, D.S. 1963. Sheath blight of rice caused by Rhizoctonia solani Kühn, a new record in India. Current Science 32:320-329.

Rajan, C.P.D. 1987. Estimation of yield losses due to sheath blight disease of rice. Indian Phytopathology 40: 174-177.

Ramakrishnanan, T.S. 1971. Diseases of rice. Indian Council of Agriculture Research, New Delhi p. 150.

Roy, A.K. 1986. Survival of sclerotia of Rhizoctonia solani f.sp Sasakii in relation to moisture regime of soil. Indian Phytopathology 39: 259-263.

Singh, R.S. 1998. Plant Diseases. $7^{\text {th }}$ Edition, Oxford \& IBH Publishing Co. Pvt. Ltd., New Delhi. pp 489-492.

\section{How to cite this article:}

Mohammad Najeeb Mughal, Mushtaq Ahmed, Sabiya Bashir, Ali Anwar, K.A. Bhat, Z.A. Lone, Imran Bashir, N.A. Bhat, Zahoor Ahmed Dar, Mudasri Ahmed Bhat, Seerat un Nissa, R.A. Wani and S.A. Hakeem. 2017. Perpetuation of Rice Sheath Blight Pathogen (Thanatephorus cucumeris) Under Temperate Conditions of Kashmir, India. Int.J.Curr.Microbiol.App.Sci. 6(11): 3706-3713. doi: https://doi.org/10.20546/ijcmas.2017.611.434 